\title{
Announcement
}

\section{Special Issue on}

\section{Artificial Water Reservoir Triggered Earthquakes at Koyna, India}

Under some favorable geological conditions, filling of artificial water reservoirs can trigger earthquakes. The M 6.3 Koyna earthquake of December 11, 1967 is the largest artificial water reservoir triggered earthquake globally. The Koyna region continues to be seismically active and as of now 22 earthquakes of $M \geq 5.0$; and over 200 earthquakes of $M \geq 4.0$ and several thousand smaller earthquakes have occurred in the region. These earthquakes occur in a small area of $20 \mathrm{~km} \mathrm{x} 30 \mathrm{~km}$, are shallow (most events between $2 \mathrm{~km}$ to $7 \mathrm{~km}$ depth), and there are no other earthquake sources within $50 \mathrm{~km}$ of Koyna region. This makes the region extremely suitable for near source study of earthquakes. The question of setting a borehole observatory to investigate triggered earthquakes was discussed in two International Continental Drilling Program (ICDP) Workshops. These workshops very strongly supported setting up of the borehole laboratory. The drilling of the first pilot borehole of $3 \mathrm{~km}$ depth has just started.

In December 2017, we shall be completing fifty years of the December 1967 Koyna earthquake. It is proposed to dedicate the December 2017 issue of the Journal of the Geological Society of India to Koyna earthquakes. Contributions are invited on geology/geophysics related issue of earthquakes at Koyna. Please submit your manuscript not exceeding 6000 words including diagrams (a full page diagram is equivalent to 1300 words, and a one-half page equivalent to 700 words) on the format of the Journal of the Geological Society of India to the Guest Editor, Prof. Harsh K. Gupta (E-mail: harsheseg@gmail.com) on or before 31 st May 2017. All manuscripts shall undergo usual review process.

Statement about ownership and other particulars about newspaper 'Journal of the Geological Society of India' to be published in the first issue every year after the last day of February

\author{
Form V Rule (8)
}

1. Place of Publication: Bangalore. 2. Periodicity of Publication: Monthly. 3. Printer's Name, Nationality, Address: M. Nagaraju, Indian, Driti Enterprises, \#117/19, Cauverynagar Main Road, Cauverynagar, B.S.K. III Stage, Bangalore - 560 085. 4. Publisher's Name, Nationality, Address: R.H. Sawkar, Indian, Geological Society of India, 63, Basappa Layout, Gavipuram Extension, Bangalore - 560 019. 5. Editor's Name, Nationality, Address: B. Mahabaleswar, Indian, Geological Society of India, 63, Basappa Layout, Gavipuram Extension, Bangalore - 560 019. 6. Names and address of individuals who own the newspapers and partners or shareholders holding more than one percent of the total capital: Geological Society of India, Bangalore.

I, B. Mahabaleswar, hereby declare that the particulars given above are true to the best of my knowledge and behalf.

Dated: 1 March, 2017

(Sd.) Mahabaleswar

Editor, Journal of the Geological Society of India

\footnotetext{
"Printed by M. Nagaraju and Published by R.H. Sawkar on behalf of the Geological Society of India, No.63, 12 ${ }^{\text {th }}$ Cross, Basappa Layout, Gavipuram, Bengaluru - 560019 and Printed at M/s Driti Enterprises, No.117/19. Cauverynagar Main Road, B.S.K. $3^{\text {rd }}$ Stage, Bengaluru - 560085 and Published at the Geological Society of India, No.63, 12 ${ }^{\text {th }}$ Cross, Basappa Layout, Gavipuram, Bengaluru - 560 019" - Editor: B. Mahabaleswar.
} 